\title{
Entre la tradición y la modernidad. Las ceremonias públicas gallegas en el reinado de Fernando VII
}

\author{
ROBERTO J. LÓPEZ*
}

\begin{abstract}
RESUMEN
ABSTRACT

Se analizan en este trabajo las

Public ceremonies during the ceremonias públicas gallegas del Fernando VII reign in Galice are analyzed in this work trying to integrate them into the general context of public opinion formation and the particular economic and social context in Galice in that time. So, we can understand the public ceremonies of 1808-1833 as the expression of a society with a strong discussion inside between two great social and economic models, absolutist and liberal, and with a special predominance of the traditional principles.
\end{abstract}

\section{INTRODUCCIÓN}

El período correspondiente al reinado de Fernando VII es una época convulsa y rica en acontecimientos políticos que se inscriben en el contexto de unos cambios profundos, aunque no inmediatos, en la trayec-

* Departamento de Historia-II. Universidad de Santiago de Compostela. 
toria histórica de España. Desde la perspectiva de análisis que se adoptará en las páginas que siguen, el aspecto más relevante de ese contexto de cambios es la existencia de un debate de fondo entre dos modelos políticos y sociales muy diferentes: el de los partidarios de una soberanía regia de perfil absolutista, y el de los partidarios de un giro del sistema -en mayor o menor medida- hacia una monarquía constitucional, o lo que es lo mismo hacia el establecimiento de un sistema político - que no era sólo político- basado en la soberania nacional ${ }^{\text {. }}$ Nuestra pretensión es la de ilustrar una parte de ese debate en la sociedad gallega del período a través de una de sus expresiones, las ceremonias públicas que se sucedieron al compás de los acontecimientos del reinado fernandino. Partimos de la hipótesis de que tales celebraciones constituyeron uno de los vehículos de transmisión de los principios que se discutian, y que además de transmitirlos contribuyeron eficazmente a su consolidación. Más concretamente, y dicho de manera muy resumida, partimos del supuesto - que trataremos de confirmarde que las ceremonias públicas del período sirvieron para elaborar y consolidar los mitos que harán fortuna en el siglo $x \mid x$, el mito reaccionario y el mito liberal.

Antes de adentrarnos en los contenidos específicos de las ceremonias públicas gallegas entre 1808 y 1833 , es conveniente trazar su contexto general en dos de las vertientes que pueden resultar más significativas. De un lado, el marco interpretativo en el que cabe incluir el fenómeno ceremonial como medio de comunicación en la fase final del Antiguo Régimen; de otro, el panorama general de Galicia en esa época. Establecidas de este modo las referencias que pensamos son las más oportunas, evitaremos reiterar innecesariamente los argumentos que a nuestro juicio ayudan a comprender el significado y valor de las ceremonias públicas gallegas del período.

El debate historiográfico sobre la crisis del Antiguo Régimen en España fue abierto entre otras, por las obras de Atitol.A. M. Antiguo Régimen y revolución liberal. Barcelona, 1978; Fontana, J.. La quiebra de la Monarquía Absoluta, 1814-1820. Barcelona, 1971; y NaIjal, J. El fracaso de la Revolución Industrial en España. 1814-1913. Barcelona, 1974, y cuyos resultados siguen vigentes al menos de manera parcial. Las investigaciones posteriores han permitido establecer diferentes modelos y ritmos en la transición según las condiciones particulares de los territorios españoles, como se pone de manifiesto en SAAVEDRA, $P$. y $V_{1-}$ LLARES, R. (coordinadores). Señores y campesinos en la Peninsula lbérica. siglos XVIII-XiX, 2 vols. Barcelona, 1991. En cualquier caso, se trata de un debate todavía abierto; véanse al respecto Garcia, E. y StRnA, J., La crisis del Antiguo Régimen y los absolutismos. Madrid, 1994, y Ruiz Torres, P., "Del Antiguo Régimen al Nuevo Régimen: carácter de las transformaciones", en Antiguo Régimen y liberalismo. Homenaje a Miguel Artola, volumen I. Madrid, 1994 , págs. 154-192 


\section{LAS CEREMONIAS PÚBLICAS Y LA GÉNESIS DE LA OPINIÓN PÚBLICA}

Una función importante de las ceremonias públicas del Antiguo Régimen, aunque no la única, fue la de servir como medio de comunicación de determinados acontecimientos políticos; un medio de comunicación con un rasgo peculiar, por su marcado carácter propagandistico ${ }^{2}$. El estudio de las ceremonias públicas del período final de la Edad Moderna consideradas como medio de comunicación, adquiere un tono particular si se integra en el de la génesis de la opinión pública. En este caso, la referencia a la tesis de Habermas se hace poco menos que obligada?

Según Habermas, durante la Edad Moderna se fue produciendo de manera paulatina $-\mathrm{y}$ sobre todo a partir de mediados del siglo xVIII- una modificación sustancial de las relaciones entre lo público y lo privado en el ámbito de la política y de sus manifestaciones. En síntesis, esa transformación habría desembocado en el establecimiento de un espacio público en el que confluían opiniones privadas, que dejaban de serlo en la medida en que desde ese espacio público lograrán afectar a las cuestiones públicas. Se trató, en suma, de un proceso por el que:

"el público compuesto por personas privadas raciocinantes [en general, los burgueses] se apropia de la publicidad reglamentada desde arriba, convirtiéndola en una esfera de crítica del poder público» ${ }^{4}$.

Como ya se señaló anteriormente, este proceso se inicia, según la tesis de Habermas, a finales del siglo XVII, si bien no será hasta finales del XVIII cuando se pueda considerar como plenamente establecido y estructurado ${ }^{5}$.

Sobre las diferentes funciones de las ceremonias públicas de la Edad Moderna, LOPEZ, R. J. "Ceremonia y poder en el Antiguo Régimen. Algunas reflexiones sobre fuentes y perspectivas de análisis", en Simposio "El rey ausente". Pamplona, 1997, en prensa.

HABEAMas, J. Historia y critica de la opinión pública. La transformación estructural de la vida pública. Barcelona, 1982.

lbidem. pág. 88.

Ibidem, págs. 64 y 124-136. Sobre la pertinencia de situar el origen de la «opinión pública» en Francia a partir de mediados del siglo XVII, BAKER. K. M., "Politique et opinion publique sous l'An. cien Régime", Annales E.S.C., 1 (1987), págs. 41-71. La crítica al poder público y el enfrentamiento de opiniones sobre la politica española sigue en términos generales el mismo proceso que el señalado en Francia: de manera muy clara esa opinión se manifiesta en el cambio de dinastia, y a partir de ahi sigue un curso creciente, a través de la prensa y otros medios. Al respecto son de utilidad las obras de Penez Picazo, M. T., La publicística española en la Guerra de Sucesion. Madrid, 1966, 2 vols. y en particular las de EGlDO, T., Prensa clandestina española del siglo xvII!. "El Duende Critico". Valladolid, 1968; Opinión pública y oposición al poder en la España del siglo xvii. Valladolid, 1971: "La oposición y el poder: el desastre de Argel (1775) y la sátira política", en Actas del Congreso Internacional sobre Carlos III y la llustración, t. I. Madrid, 1989, págs. 423-449. 
Una razón para situar en el ecuador del siglo la consolidación de la opinión pública es que es a partir de estos años centrales es cuando se puede apoyar en instrumentos e instituciones concretas y más o menos sólidas, como los salones, las academias, las sociedades económicas, el avance de la edición y lectura de libros y la consolidación de la prensa periódica entre otras. De esta manera se irá perfilando una situación inédita, la consolidación de una instancia nueva e informal por cuanto no se corresponde con ninguna institución, en la que se discuten y critican las decisiones del poder. A partir de entonces la opinión pública deberá ser escuchada y a veces ser convencida; la monarquía se verá obligada a entrar a finales del siglo XvIII en un juego en el que nunca antes había participado: el de explicar, persuadir y convencer ${ }^{6}$. Desde el punto de vista de los contenidos, por tanto, la opinión pública se caracteriza por ser un espacio de discusión política, sustraído a la influencia del poder público y crítico con respecto a sus actos e incluso sus fundamentos. Sociológicamente, se trata de un fenómeno burgués, al margen tanto de las instituciones de gobierno como de las clases populares; según Habermas, éstas se encuentran oprimidas y por tanto sin posibilidad de acceso a la opinión pública y a sus vehículos?

El contexto en el que Habermas inserta el origen de la opinión pública es, por tanto, el correspondiente a una transformación de la estructura social del Antiguo Régimen, con sus contradicciones y tensiones. El efecto más inmediato -al menos el que más inmediatamente nos interesa para nuestro trabajo- es el de una consecuente modificación en la forma de considerar la res publica y con ella de las formas propagandísticas. No es necesario acumular muchas más evidencias a las ya disponibles para poder afirmar que la progresiva desacralización de la imagen del rey y de la monarquia es un hecho constatable a partir de las décadas finales del siglo XVIII en Francia, pero también en España ${ }^{8}$. Ante este hecho se reac-

\footnotetext{
CHARTIER, R., Espacio público, crítica y desacralización en el siglo Xvill. Barcelona, 1995, págs. $42-43$

En este aspecto, el sociológico, convendrá llamar la atención sobre la existencia de una cierta opinión popular, también con contenidos políticos. Sobre esta cuestión, BURKE, P., La cultura popular en la Europa moderna. Madrid, 1991, págs. 362-376, y sobre todo FARGE, A., Dire et mal dire. L'opinion publique au xvmi siècle. París, 1992, obra que continúa la investigación allí donde la dejó Habermas, en el caso de la opinión pública plebeya o popular

Sobre el progresivo deterioro del carácter sagrado de la monarquía francesa en el siglo XVill, Chartier, R., Espacio público.... op. cit., págs. 127-151; y Merrick, J. W., The desacralization of the French Monarchy in the Eighteenth Century. Londres, 1990. En algunos textos de la segunda mitad del siglo XVIII podemos encontrar algunos atisbos de una posible desacralización de la imagen real en España. Nos referimos a aquellos sermones y elogios en los que junto a los tópicos habituales sobre las elevadas virtudes del monarca aparecen méritos de gestión y gobierno: es decir, se presenta al rey como bueno tanto por ser rey como por los logros de su gestión, o lo
} 
cionará en el caso de España -y en particular en Galicia- en dos direcciones fundamentales que se pueden comprobar en los contenidos de las ceremonias públicas. De una parte, la acentuación de los valores tradicionales de la monarquia, en un intento de frenar el proceso de disolución de las formas políticas del Antiguo Régimen. Y de otra, el empleo de las ceremonias públicas para difundir valores emergentes como la igualdad, la libertad, la legalidad, la nación y otros ${ }^{9}$. Así, y con relación a las ceremonias públicas anteriores, las de los años finales del siglo XVIII y sobre todo las del reinado fernandino presentan rasgos diferentes, aunque se mantengan ciertas formalidades. En general, se abandona el uso de significantes ambiguos o escasamente redundantes, para emplear sistemas de representación precisos y claros, cuya descodificación se pueda prever por el autor y sus claves sean de fácil acceso a la mayor parte de la población, por ser menos arbitrarias y más directas las imágenes y símbolos empleados. De todo ello tenemos numerosos ejemplos, tanto en las ceremonias del absolutismo como del liberalismo.

\section{GALICIA EN LA CRISIS DEL ANTIGUO RÉGIMEN}

Para comprender mejor el simbolismo y significado de las ceremonias públicas gallegas del período fernandino, es conveniente tener en cuenta, además de las consideraciones anteriores, el panorama histórico general de Galicia en este período histórico. Es necesario retroceder unas décadas y situar el punto de arranque de estas consideraciones a mediados del siglo XVIII para abarcar con más amplitud el contexto del reinado de Fernando VII. No se trata de hacer aquí un recorrido detallado por la evolución gallega de la época, tarea llevada a cabo por otros historiadores; se

que es lo mismo por sus condiciones y capacidades humanas. Así, se elogia de Fernando VI el plan de la Única Contribución, la creación de cuarteles militares, la formación de Hospicios Reales y Academias, y otras iniciativas, en ARIAS SOMOZA, A., Oración fúnebre... en las reales exequias a la gloriosa memoria del... Sr. D. Fernando VI. por la Santa lglesia Cathedral de Mondoñedo.... Imp. de Joaquín Ibarra. Madrid, s.a. [1759], págs. 16-22; y de Carlos III el impulso y reforma de los estudios universitarios, el establecimiento de las Nuevas Poblaciones, la creación de las Sociedades Económicas, de Juntas y Consulados, entre otras acciones de gobierno, en LOSADA CADÓRNigA, A., La sabiduría de los reyes o Carlos el Sabio, Santiago, Imp. de Ignacio Aguayo, 1789, págs. 20-36. Insistimos en que estas referencias son sólo un posible síntoma pues conviven, a veces en el mismo texto, con expresiones y argumentaciones claramente alineadas con la defensa del origen divino del poder y por tanto con la sacralidad regia.

9 En cualquier caso, convendrá recordar lo que ya hace años recordó Herrero, que el conflicto entre Antiguo Régimen y sociedad moderna no fue un problema característico de España, sino que abarcó a Europa entera; véase HERRERO, J., Los orígenes del pensamiento reaccionario español. Madrid, 1973, pág. 22. 
trata tan sólo de señalar puntos de referencia que sirvan para situar en un contexto preciso los fenómenos de transformación apuntados en el apartado precedente, y aportar las claves de carácter político, económico y social que permitan entender mejor a qué realidad responden los elementos y los mensajes que transmitieron las ceremonias públicas gallegas entre 1808 y 1833.

Debemos empezar diciendo que en la segunda mitad del siglo xvIII y en Galicia se produjo, como en otros lugares, una conjunción de reformas e innovaciones que ofrecian la posibilidad de acometer con ciertas probabilidades de éxito una transformación en profundidad de su estructura tradicional. Las investigaciones de las tres últimas décadas han puesto de relieve la inexactitud de algunos planteamientos precedentes, que apoyaban su interpretación del pasado gallego en una multisecular tradición de atraso, impermeabilidad al progreso y a la innovación y otras categorías similares. Como en todo, algo de esto hay de cierto en estas afirmaciones, pero sólo en parte y sobre ello volveremos en breve.

Frente a la visión de una Galicia atrasada "por naturaleza», los resultados más recientes nos han "redescubierto" una Galicia que al menos en términos generales presentaba aspectos prometedores en la segunda mitad del siglo xvIII. Así, y sin ánimo más que de esbozar referencias de interés, cabe señalar que desde el punto de vista del comportamiento de la población, en buena parte de Galicia es observable en el siglo xvIII el inicio de la transición hacia un régimen demográfico moderno, y que si bien la población era abrumadoramente rural, se aprecia en estas décadas un cierto despegue en algunas concentraciones urbanas provocado por iniciativas políticas y económicas, en concreto en La Coruña, Ferrol y Vigo ${ }^{10}$. En cuanto a la estructura económica, se deben resaltar los avances logrados en el sector agropecuario, y las oportunidades que ofrecían la pesca y la industria textil, asi como algunas iniciativas derivadas de disposiciones de la Corona, como el establecimiento de los Reales Arsenales en Ferrol, la apertura al comercio colonial del puerto de La Coruña, y la in-

Uno de los rasgos específicos de la demografía gallega de la Edad Moderna es el extra. ordinario peso de lo rural sobre lo urbano; así, mientras la tasa de urbanización europea a finales del xvIII está muy próxima al $12 \%$, la de Galicia en los mismos años era de un $4 \%$. Sobre las caracteristicas de la población gallega del xvIII y comienzos del $x i x$, pueden consultarse los siguientes trabajos: DUBERT, I., "Familia, inmigración y espacio urbano en la historia de Galicia. Santiago de Compostela, siglos XVIII-X|X», en Imágenes de la diversidad: el mundo urbano en la Corona de Castilla (ss. xvi-xVIII). Santander, 1997, págs. 201-244; EIRAS, A., La población de Galicia, 17001860. La Coruña, 1996; SaAvedra, P., "Las grandes tendencias comarcales en la evolución de la población gallega (de comienzos del XVII a mediados del XIX)». Studia Historica, XI (1993), págs. 11-59. 
dudable mejora - aunque insuficiente - que para las comunicaciones supuso la construcción del Camino Real que enlazaba La Coruña con Madrid ${ }^{11}$. En resumen, en los años 70 y 80 del siglo xvill parecía existir un ambiente propicio para iniciar un cambio, encabezado por una burguesía comercial y empresarial que se movía en torno a estas actividades.

El aprovechamiento de estas posibilidades requería una necesaria transformación de las actitudes e intereses de las elites gallegas. $Y$ es precisamente en este punto donde naufragaron las posibilidades de cambio que tan brevemente acabamos de citar. En su mayor parte, los rendimientos generados por la actividad económica (en buena medida de carácter agrícola y ganadero) fueron muy escasamente reinvertidos en la propia actividad; por el contrario, se emplearon en la reproducción de rentas seguras - como lo eran los foros agrícolas- y en gastos de carácter suntuario. Esta forma de actuar, poco o nada propensa al riesgo y que en lugar de remover las estructuras tradicionales las apuntalaba, se reforzó con el comportamiento de aquellos agentes económicos que en períodos distintos de la segunda mitad del siglo XVIII participaron en alguna de las iniciativas industriales y comerciales antes mencionadas. Estas en general fracasaron, a veces por razones técnicas, otras por su limitada capacidad para competir en un mercado cada vez más amplio, y en definitiva por la muy escasa mentalidad empresarial de la incipiente burguesía gallega. En consonancia con el último rasgo mencionado, la reacción ante las dificultades de una parte importante de quienes estaban embarcados en estas iniciativas fue la de invertir los beneficios obtenidos en la compra de tierras para asegurarse de este modo unas rentas más o menos constantes y poco volátiles; es decir, unirse a aquellos sectores de la sociedad gallega que tradicionalmente habian hecho de las rentas agrarias el fundamento de su situación económica, prestigio social y llegado el caso también de su influencia política ${ }^{12}$.

\footnotetext{
Véanse, entre otros estudios, EIRAS, A., "Dîme et mouvement du produit agricole en Galice, 1600-1837", en Estudios sobre agricultura y población en la España moderna. Santiago de Compostela, 1990, págs. 85-110; PEREZ GarciA, J. M., "A agricultura galega e os seus rendementos. Un estudio evolutivo, 1700-1850", Revista Galega de Estudios Agrarios, 9 (1983), págs. 35-70; CARMONA, J., "Igualdade e desigualdade nas pesquerías galegas de mediados do século XVIIl", Grial. 102 (1989), págs. 216-226; Rodriguez Ferreiro, H., "Consecuencias del establecimiento de los fomentadores catalanes en las Rías Bajas en el siglo XVIII", en Obradoiro de Historia Moderna. Homenaje al Prof. Antonio Eiras Roel. Santiago de Compostela, 1990, págs. 269-296; CARMONA, J., El atraso industrial de Galicia: auge y liquidación de las manufacturas textiles (17501900). Barcelona, 1990; Alonso Ál varez, L., Comercio colonial y crisis del Antiguo Régimen en Galicia (1778-1818). [Santiago de Compostela], 1986; Garcia-Fuentes de LA Fuente, M., El Camino de acceso a Galicia en el siglo xvil. La Coruña, 1987.

Además de la bibliografía citada en la nota anterior, véanse Alonso Álvarez, L., Industrialización y conflictos sociales en la Galicia del Antiguo Régimen. 1750-1830. Madrid, 1977; del
} 
La consolidación de las estructuras tradicionales en la Galicia de finales del XVIII no se debe relacionar en nuestra opinión con una carencia de recursos, pues hay suficientes evidencias como para afirmar lo contrario, sino con los comportamientos de la sociedad gallega en su conjunto, y de manera particular de quienes la encabezaban, con la peculiaridad de que en Galicia la elite social era un grupo un tanto difuso, entretejido por relaciones horizontales y verticales que sirvieron de freno eficaz a los intentos de reforma que se ensayaron ${ }^{13}$. Por su parte, los grupos populares y de manera especial el campesinado que constituía la mayor parte de la población, se vio reforzado progresivamente en sus sistemas de vida y organización tradicionales. Así se entiende el bajo nivel de las tensiones sociales y que sus estallidos más violentos tuvieran como objetivo no a los propietarios de tierras y beneficiarios de las rentas agrarias (foros y diezmos), sino aquellas iniciativas que iban derechamente contra las formas de organización tradicionales ${ }^{14}$. En este orden de cosas, resulta sintomático el recurso a la emigración -en aumento según transcurren las últimas décadas del XVIII- como solución de emergencia para los problemas de una estructura social y económica que apenas atendía las necesidades de la gran masa de población ${ }^{15}$. En definitiva, se trataba de una sociedad que en general no estaba dispuesta al cambio y que encontró en las dificultades de la actividad económica los pretextos suficientes para no aprovechar las posibilidades - limitadas, pero posibilidades al fin y al cabode reforma que ofrecían los recursos económicos disponibles.

Esta fortaleza de la sociedad tradicional gallega, como ha sido descrita por algunos historiadores, tuvo sus consecuencias en las actitudes políticas de los años finales del siglo XVIII y de manera especial en las convulsiones del reinado de Fernando VII. Predominó de forma abrumadora la defensa de los privilegios tradicionales, con una fuerte aversión a concep-

mismo, "Comerciantes e políticos. Economia e ideoloxia na burguesía galega da primeira mitade do século XIX", en VI Xornadas de Historia de Galicia. Mentalidades colectivas e ideoloxia. Orense, 1991, págs. 10-19; Garcia-Lombardero, J., La agricultura y el estancamiento económico de Galicia en la España del Antiguo Régimen. Madrid, 1973; SaAvedRa Fernandez, P., "Desarrollo y crisis de la industria textil en Galicia. La lencería, 1600-1840», Cuadernos de Investigación Histórica, 7 (1983), pág. 113-132.

13 Fernandez Gonzalez, A., "Los grupos de poder local en Galicia, 1750-1850", Noticiario de Historia Agraria, 9 (1995), págs. 129-153.

14 Gonzalez-Pola, P., Sargadelos 1798. Un motín en la Galicia de finales del Antiguo Régimen. Sada (La Coruña), 1994; SauRin dE la IGLESIA, M. R., Reforma y reacción en la Galicia del siglo XVIII (1764-1798). La Coruña, 1983.

15 Rey CASTELAO, O., "Migraciones internas y medium-distance en Galicia, siglos XVI-XIX", en Migraciones internas y medium-distance en la Peninsula lbérica, 1500-1900. Santiago de Compostela, 1994, págs. 85-130. 
tos que eran contrarios a éstos, como el constitucionalismo, la soberanía nacional y otros del mismo ámbito. No obstante, existieron grupos más o menos organizados de liberales que a pesar de su escaso número y de su reducida distribución geográfica, supieron dar la réplica al tradicionalismo gallego ${ }^{16}$. Conviene decir, sin embargo, que el resultado final de tal réplica no fue la ruptura de la sociedad tradicional, sino una cierta componenda entre liberales y sectores sociales dominantes tradicionales, que sirvió para introducir algunas reformas, pero no para cambiar el conjunto de relaciones y de organización de la sociedad gallega. La transición del Antiguo al Nuevo Régimen fue una revolución frustrada ${ }^{17}$.

Éste es de manera apresurada el contexto en el que deben interpretarse las ceremonias públicas gallegas del reinado de Fernando VII. Un contexto caracterizado por la defensa de unos principios tradicionales, y en el que los partidarios de un nuevo orden eran pocos y en general con menos recursos. En cualquier caso y a pesar de la desproporción, el enfrentamiento entre unos y otros encontró en las celebraciones una ocasión para expresar públicamente sus argumentos y aspiraciones. En último término, las ceremonias se pueden interpretar como una traslación a las calles y plazas de las discusiones de las sesiones constituyentes, de las acaloradas polémicas periodísticas y librescas, de las conversaciones de gabinete y de eruditos; es decir, un traslado acomodado a la capacidad de asimilación de las masas populares de unas ideas y planteamientos que encerraban un alto grado de abstracción. Por todo esto, y sin que lo sucedido en Galicia sea una excepción, nos encontramos con unas ceremonias públicas que están a medio camino entre la tradición y la modernidad, en la medida en que conjugan formas y contenidos de épocas pasadas con otras que responden mejor a la función más didáctica y adoctrinadora que las ceremonias de este período tuvieron en relación a las precedentes. Dicho de otra manera y volviendo a las tesis de Habermas, unas ceremonias que responden a la necesidad de convencer a la opinión pública,

\footnotetext{
15 El liberalismo gallego de las primeras décadas del siglo $\times 1 \times$ fue una corriente minoritaria, aunque cualitativamente relevante, asentada en núcleos urbanos de peso como La Coruña, Santiago y Vigo. Sus partidarios estaban profesionalmente vinculados en algunos casos a la Universidad, en otros - los menos- a la Iglesia, y en su mayor parte a la magistratura, la medicina, el comercio y el funcionariado; y apoyada discretamente por la incipiente masoneria gallega. Sobre estos y otros aspectos, véanse los trabajos de BARREIRO FERNÁNDEZ, X. R., Liberales y absolutistas en Galicia (1808-1833). Vigo, 1982; CENDON AMARO, A., "A Universidade de Santiago na primeira metade do século xix (1807-1857)", Revista Galega do Ensino, 11 (1996), págs. 79-121; y Valin, A., Galicia y la masoneria en el siglo xix. Sada (La Coruña), 1990.

Tomamos la expresión de BARREIRO FERNANDEZ, X. R., "De la guerra contra el francés a la carlistada", en Historia de Galicia, vol. 3. Vigo, 1991, págs. 689-708.
} 
bien sea de las bondades del absolutismo como de las del liberalismo, y que por lo tanto son adaptadas a su nueva función.

\section{LOS MITOS DEL REINADO FERNANDINO}

El reinado de Fernando VII puede estudiarse en Galicia siguiendo el mismo esquema cronológico básico utilizado para el resto de España; pero habida cuenta de que nuestro interés no está tanto en los hechos políticos en sí como en su reflejo simbólico y ceremonial, simplificaremos el esquema habitual para fijarnos en este aspecto ${ }^{18 .}$

A nuestro entender, el abundante cúmulo de ceremonias públicas del reinado fernandino en Galicia puede organizarse en torno a tres ejes fundamentales, que tienen en común una misma elaboración conceptual, la formación de los mitos. En un primer momento, el intento de mitificación del propio monarca Fernando VII como el "Deseado", y una vez superado este inicial fervor fernandino, la elaboración de otros dos mitos más amplios y que entrarán en pugna al ser utilizados como arma política, el mito absolutista y el mito liberal. Nos parece que al abordar el estudio de las ceremonias públicas bajo esta perspectiva, se aúnan adecuadamente los dos marcos de referencia descritos en los apartados precedentes, el de la formación y utilización de la opinión pública y el del contexto histórico especifico de Galicia en esos años.

Antes de proseguir, trataremos de especificar en lo posible la idea de mito con la que trabajaremos. De forma genérica, se puede entender el mito como la simbolización y conversión en imágenes, no siempre racionalizables, de una serie de tendencias, aspiraciones y temores de una sociedad -o parte de ella- y en un período histórico determinado ${ }^{19}$. Este proceso de mitificación o de elaboración de un mito, cumple diversas funciones en el seno de la sociedad o del grupo en el que se produce. Sirve de modo general para conferir un sentido a los avatares de una sociedad, y de manera más concreta para provocar un consenso social en determinadas cuestiones que pueden ser vitales para la organización de la sociedad. Los mitos permiten establecer una corriente de identificación de los individuos con el ambiente que les rodea, aunque esta identificación sea

Un amplio resumen de los acontecimientos políticos del reinado se puede encontrar en Barraeiro Fernandez, X. R., Galicia. Historia. VII: Historia Contemporánea. Política (siglo xix). La Coruña, 1991.

Tomamos esta descripción de Eco, U., Apocalípticos e integrados. Barcelona, 1990, pág 219. 
únicamente simbólica y por tanto con posibles fuertes dosis de ilusión ${ }^{20}$. El consenso se logra, por tanto, en la medida en que se produce el reconocimiento de la fuerza unificadora del mito, y bajo ésta se equilibran de alguna manera las posibles discrepancias y contradicciones. Lo importante de la elaboración mítica no es tanto lo que significa concretamente, sino la reunión de voluntades que es capaz de suscitar de facto en relación a determinadas cuestiones ${ }^{21}$.

Y en consonancia con todo esto, el mito cumple otra función, la de responder y servir a las exigencias del control social. Según Roland Barthes, la forma en la que básicamente actúan los mitos es «naturalizando» la historia, es decir, presentando sus significaciones como inherentes a las cosas y como una exigencia de su propia naturaleza, no como resultado de procesos históricos y sociales. Este modo de significar es el que para Barthes pone en evidencia que los mitos son en realidad el producto de una clase o un grupo social que consiguió el dominio a través de una determinada historia, cuyo dominio quiere consolidar o perpetuar mediante ese oscurecimiento de sus orígenes políticos y sociales que constituye el mito ${ }^{22}$. De esta forma, el control sobre la elaboración del mito permite el control -al menos en ciertos aspectos- sobre las opiniones dispares; un control que consiste en este aspecto en la posesión de las claves para interpretarlo ${ }^{23}$.

No nos parece que sean necesarias demasiadas explicaciones para considerar como elaboraciones míticas las tres que señalamos anteriormente. Los tres casos responden a la necesidad de explicar una situación histórica precisa tratando de "naturalizarla» en el sentido que antes se mencionó; intentan buscar un amplio consenso social sobre los valores que cada una de ellas representa; y desde luego, lo que se busca es el control del poder por parte de quienes hacen público ese mito mediante la simbología desplegada en las ceremonias públicas -aunque no sólo en las ceremonias- de cada caso.

\section{LA IMAGEN INICIAL DE FERNANDO VII: EL REY DESEADO}

La llegada al trono de Fernando VII estuvo revestida de unas circunstancias tan particulares que la convirtieron en un hecho singular

Véase J. Fiske. Introduçâo ao estudo da comunicaçâo. Porto. 1995, pág. 228

ECO, U., Semiótica y filosofía del lenguaje. Barcelona, 1990, págs. 273-274.

Sobre el mito según Barthes, FISKE, J., Introducçâo ao estudo..., op. cit., págs. 121-122

Eco. U., Semiótica y filosofia... op. cit., pág. 274. 
dentro de la monarquía hispana del Antiguo Régimen. Como es bien sabido, Fernando VII ocupó el trono tras la abdicación de su padre, Carlos IV, el 19 de marzo de 1808. La abdicación fue el resultado inmediato del motín de Aranjuez (18 de marzo); pero en realidad fue la consecuencia del intenso descontento arrastrado durante años contra el gobierno de Carlos IV y en particular de la actuación de su ministro Manuel Godoy. De esta forma y por vez primera en la historia moderna española, un monarca es obligado a renunciar al trono por su mala gestión y a abdicar en su sucesor, al que se consideraba como la posible solución para los males de España. Planteadas así las cosas, parece evidente que el monarca ya no contaba con las simpatías incondicionales de sus súbditos; Carlos IV no supo ganárselas, y a Fernando VII no le quedaba más remedio si quería permanecer en el trono que cumplir con todo aquello que se le demandaba. Los monarcas habían perdido al menos parcialmente aquel halo sagrado que los situaba por encima de las críticas, y empezaban a estar sujetos a la opinión y al control de sus actuaciones y decisiones.

Otro hecho vino muy pronto a incidir sobre la situación política española y sobre la imagen de Fernando VII, la prisión en Bayona de la familia real y la renuncia a los derechos sobre el trono español en favor de Napoleón en los primeros días de mayo de 1808. Si peculiar fue entonces la llegada al trono de Fernando VII, peculiar si es que puede hablarse así fue su situación hasta 1814 en que por fin regresa y vuelve a ocupar el trono. La situación española entre 1808 y 1814 resulta especialmente compleja: el rey legítimo ha sido sustituido por José Bonaparte, el país se enfrenta a la ocupación de las tropas napoleónicas, y al tiempo - y favorecido por las razones anteriores- se desata un fuerte debate interno sobre la necesidad de modificar el régimen de gobierno, y que tendrá su máxima expresión en las reuniones y acuerdos de las Cortes de Cádiz.

Desde el punto de vista que nos interesa, debemos subrayar sobre todo el efecto que todo esto tuvo sobre la imagen de la monarquía y en particular de Fernando VII hasta su vuelta en 1814. Todo apuntaba de forma casi inevitable hacia su revalorización, hasta llegar a su mitificación. El rey Fernando VII se convierte realmente en el "Deseado". Había llegado al trono por medio de una revuelta popular, lo cual ya le había otorgado de partida una mayor proximidad a los súbditos que la que gozaron sus antecesores; su pronta prisión en Bayona hizo de él otra víctima de Napoleón, lo que le aproximó todavía más, sentimiento que fue convenientemente alimentado hasta su vuelta tanto por los partidarios de la tradición como por los defensores de los cambios, ha- 
bida cuenta del vacio de poder provocado por la ausencia del monarca legítimo ${ }^{24}$

En este ambiente, las ceremonias públicas como manifestación externa del poder, ya no podían presentar el mismo perfil que en los siglos anteriores. No podian limitarse a presentar una imagen mayestática de la realeza; debían ser más directas y sobre todo lograr afianzar la adhesión al rey ausente y prisionero en Bayona, al que se le presentará como el garante de la paz y de la prosperidad perdidas primero con el mal gobierno de Carlos IV y después con la invasión napoleónica y la ocupación del trono por José Bonaparte. Hasta la vuelta de Fernando VII en 1814 , hay un cierto consenso entre reaccionarios y reformistas sobre la imagen del rey Borbón, consenso aparente pues cada tendencia esperaba ser la beneficiaria de las decisiones reales en su momento. Puede decirse que hasta el retorno del monarca, se mantendrá latente la división que los movimientos de reforma introdujeron y que en esencia afectaban a cuestiones tan vitales y centrales del régimen político como la inviolabilidad del monarca y la titularidad de la soberanía. Será a partir de la toma de posición de Fernando VII a favor del absolutismo que tal estado de latencia se rompa, y las manifestaciones externas del poder harán un mayor hincapié en justificar un régimen $u$ otro por encima de la persona de Fernando VII.

Entre 1808 y el retorno del rey en 1814 fueron abundantes las celebraciones públicas organizadas en Galicia. El recuento hecho en la que era una de sus poblaciones más relevantes, Santiago, indica que aquí se celebraron al menos 36 ceremonias públicas con ocasión de acontecimientos diversos, que van desde la proclamación real de 1808, hasta la celebración de la vuelta de Fernando VII, pasando por diversas rogativas por la salud real, acciones de gracias por las victorias sobre los franceses, y desde luego el apoyo de las reuniones de las Cortes y de la proclamación y jura de la Constitución de 1812. Esta profusión de ceremonias, de la que tomamos como ejemplo las compostelanas, parece confirmar aunque sea de forma periférica y secundaria dos hechos. El primero, que al tiempo que el rey José I trataba de crearse una buena imagen, las ceremonias de las que tratamos son empleadas como una especia de "contrapropa-

La Junta de Gobierno nombrada por Fernando VIl no fue capaz de cubrir ese vacio de poder; comenzaron a surgir muy pronto Juntas locales y regionales cuya única legitimidad era la voluntad del pueblo que las elegía, y que se subordinaron - no sin discusiones- a una Junta Central. Fue esta Junta la que convocó la reunión de las Cortes en Cádiz, una de cuyas decisiones más relevantes fue la aprobación de una Constitución en 1812, que establecía como régimen de la nación la monarquía parlamentaria. 
ganda» ${ }^{25}$; y el segundo, derivado de esa capacidad de "contrapropaganda", que la administración bonapartista en Galicia en la práctica apenas existió ${ }^{26}$. Que las ceremonias del período de la presencia francesa en España tuvieron ese contenido de "contrapropaganda", que sólo muy esporádicamente se advierte de forma tan clara en épocas pasadas, se desprende de varias de ellas que parecen ir dirigidas tanto a informar de determinados sucesos como a dar un apoyo moral a la población. Así, podemos citar entre otras las diversas rogativas y acciones de gracias que se sucedieron en Santiago desde septiembre hasta diciembre de 1808 para festejar diversas derrotas de las tropas francesas en Portugal y España ${ }^{27}$; la misa y Te Deum por la victoria española en Astorga en $180{ }^{28}$; y la acción de gracias por las victorias rusas sobre los franceses ${ }^{29}$. Y por supuesto se deben señalar las celebraciones de 1809 y 1810 por la liberación de Santiago del ejército francés y la victoria de Ponte San Payo ${ }^{30}$.

Lo realmente destacable es, no obstante, el reforzamiento de la imagen de Fernando VII en el contexto político ya descrito y en el contexto de una nueva mentalidad marcada por la aparición de los rituales del culto al héroe. El origen de estos rituales se encuentra en las fiestas cívicas de la Revolución Francesa, que proponían una nueva religión basada en el culto al gran hombre y a la Humanidad ${ }^{31}$. En general, estos ceremoniales novedosos suponían la plasmación simbólica de una nueva sensibilidad, la romántica, con su exaltación de la patria y la nación, cuyas aspiraciones y luchas se encarnaban en las aspiraciones y luchas de sus héroes, sobre todo en las de aquellos que daban su vida en defensa de sus ideales. La exaltación del héroe, vivo o muerto, servirá para ir creando una memoria nacional patriótica y con ella una mayor identificación y cohesión social.

\footnotetext{
25 Un breve recuento de las rogativas, procesiones y otras ceremonias llevadas a cabo entre 1808 y 1809 para crear una buena imagen de José I en Madrid y otros lugares de España, en Mercader Riba, J., José Bonaparte. Rey de España (1808-1813). Estructura del Estado español bonapartista. Madrid, 1983, págs. 453-454.

26 Sobre el régimen de gobierno de Galicia durante la ocupación, BarReiro FERNANDEZ, X. R., Galicia. Historia. VII..., op. cit., págs. 97-99.

Véase Archivo Histórico de la Universidad de Santiago (AHUS), Fondo Municipal de Santiago, Libro de Consistorios de 1808, 3er. cuatrimestre, fs. 9, 131, 146, 373 y 446.

28 AHUS, Fondo Municipal de Santiago, Libro de Consistorios de 1809, octubre-diciembre, 4. 46 .

Ibidem. Libro de Consistorios de 1813, enero-abril, ts. 293 y vio., y 384 vto.

Se recogen en PÉREz Costanti, P., Notas viejas galicianas, t. II. Vigo, 1926, págs. 305-308; y Lopez Ferreiro, A., Historia de la Santa, Apostólica, Metropolitana lglesia de Santiago de Compostela, t. XI. Santiago, 1909, apéndice XXIII

Véanse entre otros BAECQUE, $A$. de, "Le sang des héros. Figures du corps dans l'imaginairie politique de la Révolution Française", Revue dHistoire Moderne et Contemporaine. XXXIV (1987), págs. 553-586; y VOVELLE, M. (coord.), Les images de la Révolutión Française. París. 1988.
} 
Las primeras mitificaciones heroicas tuvieron como sujeto a las victimas del 2 de mayo en Madrid en el mismo año de $1808^{32}$. Al poco tiempo, en 1811, las Cortes reunidas en Cádiz decretaron que en todas las iglesias mayores de la monarquía se celebrase un funeral solemne por estas víctimas; del cumplimiento de este decreto en Santiago quedó constancia en los acuerdos municipales del mismo año 1811 y de 1813 , sin que hallamos encontrado otras referencias ${ }^{33}$. Pero en realidad no puede considerarse que fuera esta decisión de las Cortes la que marcase el inicio de la creación del héroe en Galicia; antes de 1811 encontramos esos rasgos inherentes al héroe -encarnación de valores patrios, ejemplo de virtudes y de acción, entre otros- en el recibimiento que se le hizo al Marqués de la Romana en $1809^{34}$. Y por supuesto en el tratamiento que se le otorga a la imagen de Fernando VII, al que también se le convertirá en un héroe vivo, que sufre el cautiverio y del que provendrá la salvación de la nación.

En este orden de cosas, la mitificación del monarca puede decirse que comenzó con su llegada al trono. En carta enviada al monarca por el consistorio compostelano con fecha del 20 de abril de 1808, y en la que se le comunican los actos realizados en la ciudad para celebrar su aceptación del trono, se resumen de modo grandilocuente -y por eso mismo expresivos y significativos- los más que probables argumentos y contenidos de esas celebraciones. En esa carta se le dice al nuevo monarca que:

"toda la Nación mira prefixadas en Vuestra Real Persona todas sus esperanzas, todos sus consuelos, y toda su admiración",

VARELA. J.. La muerte del Rey. El ceremonial funerario de la monarquía española (15001885). Madrid, 1990. pág. 182. Por su parte. José I decretó posteriormente el 6 de marzo de 1809 varias medidas destinadas a honrar la memoria de personajes reales y de varones ilustres, como el traslado de los resto de Jorge Juan a la parroquia madrileña de San Basilio y en Sevilla los del hebraista Arias Montano a la catedral hispalense: véase MthCADER RiBA. J.. José Bonaparte. Rey.... op. cit, págs. 558-559.

Sobre el funeral de 1811. AHUS, Fondo Municipal de Santiago, Libro de Consistorics de 1811. junio-agosto, fs. 133vto-134, donde se encuentra el decreto gaditano, y f. 226. Debe señalarse que la celebración de 1813 provocó un altercado protocolario entre el cabildo de la catedral y la corporación municipal. que tuvo sus consecuencias no sólo en este acto sino en el de la celebración ese mismo año del santo del monarca: véanse Libro de Consistorios de 1813, eneroabril, fs. 475 y vto. y el de mayo-julio, fs. 4 vto. 9 y vto, 12vto. y 157, donde se encuentran detalladas las causas del enfrentamiento entre cabildo y ayuntamiento.

Pere? Costanti. P., Notas viejas..., op cit., págs. 309-313. El encendido recibimiento del que fue objeto el Marqués en Santiago contrasta con su actuación real como jefe supremo del ejército en Galicia; su habilidad para no estar donde estaba el ejército francés le valió el apodo de "Marqués de las Romerias", y las quejas del ayuntamiento de Betanzos al monarca, entre otros. Véanse Barreiro Fernandez, X. R., Galicia. Historia... op. cit. pág. 99 ; y Martinez Santiso, M.. Historia de la ciudad de Betanzos. La Coruña, 1987 (ed. fac de la de 1892), págs. 405-412. 
y más adelante que es el:

“Ángel tutelar y firme apoyo que con la más profunda sabiduría y acierto sostendrá a sus pueblos y llegará a triunfar de nuestros más pérfidos e implacables enemigos» 35 .

Es de suponer, como se ha dicho antes, que estas ideas expuestas a Fernando VII fuesen las que se transmitieron al pueblo en los diversos actos de aclamación real celebrados entre finales de abril y los primeros días de mayo ${ }^{36}$.

La proclamación hubo de quedar en suspenso por la prisión de la familia real en Bayona, y a la espera de la decisión que adoptase la Junta Central ${ }^{37}$. Mientras tanto, la vinculación moral con el monarca cautivo se trata de reforzar, y así el 5 de enero de 1809 el ayuntamiento de Santiago acordará que al día siguiente, festividad de los Reyes Magos, los vecinos iluminen sus casas como demostración de afecto al rey detenido en Francia ${ }^{38}$. A los pocos días, el 17 de enero, la ciudad es ocupada por las tropas francesas y su consistorio parcialmente modificado; no obstante, esta ocupación durará poco pues el 23 de mayo del mismo año el ejército francés es derrotado a las puertas de Santiago. Al día siguiente, reorganizado de nuevo el consistorio, éste acuerda declarar nulo el juramento hecho a favor de José I y proclamar monarca al cautivo Fernando VII ${ }^{39}$; a los pocos días, esa vinculación formalmente reanudada con el rey Borbón se refuerza con la celebración pública de su onomástica ${ }^{40}$. Durante los años en los que todavía permanecerá ausente el rey, la festividad de San Fernando se seguirá celebrando y suponemos que con una fuerte carga propagandística ${ }^{41}$.

Esta adhesión en torno al monarca, que resultó útil como elemento de unidad ante los invasores franceses, tuvo otros vehículos de propagación

35 AHUS, Fondo Municipal de Santiago, Libro de Consistorios de 1808, 1er. cuatrimestre, fs. 270 y 271.

36 Ibidem, fs. 267 y vto, 277; y $2^{\circ}$ cuatrimestre, fs. 5 vto. y 127 . Otras noticias sobre las rogativas y luminarias en Archivo de la Catedral de Santiago (ACO), leg. 570, fs. 242vto., 244-245vto.

AHUS. Fondo Municipal de Santiago, Libro de Consistorios de 1808, 3er. cuatrimestre, $f$. 120; acuerdo del 19 de septiembre.

38 Ibidem, Libro de Consistorios de 1809 , enero y mayo-septiembre, f.6.

Ibidem. f. 36. Sobre la recuperación de Santiago, Barreiro Fernandez. X. R.. Galicia. Historia. VII..., op. cit., págs. 123-124.

: AHUS, Fondo Municipal de Santiago, Libro de Consistorios de 1809, enero y mayo-septiembre, is. 47 y vto.

41 Ibidem, Libro de Consistorios de 1811, enero-mayo, $f .404$; ibidem, Libro de Consistorios de 1812, enero-julio, ts. 286vto. y 315; ACS, leg. 542, s.f.; AHUS, Fondo Municipal de Santiago, Libro de Consistorios de 1813, mayo-julio, f. 133 vto. 
además del ceremonial público. La prensa, los pasquines, las canciones, la actuación de los clérigos desde el púlpito y el confesionario, y reuniones informales en las tabernas y otros lugares, fueron otros tanto medios que de manera diaria e insistente dieron cuerpo a la resistencia frente al invasor francés y a la idealización popular de Fernando VII ${ }^{42}$. Resulta obvio que estos y otros posibles vehículos de conformación de la opinión fueron más eficaces que las ceremonias públicas por su cotidianeidad, proximidad y adecuación a los destinatarios, y capacidad de difusión. Pero debe precisarse que las ceremonias públicas, precisamente por su carácter público, sancionaban esas opiniones particulares, y aunaban aquellas que por origen o destino podrían estar más dispersas. Esa capacidad de unificación se pone de manifiesto en el fervor desatado en 1814 con el regreso a España de Fernando VII y su restitución en el trono; fervor que en cualquier caso no debe considerarse como espontáneo en todas sus manifestaciones.

El regreso real marca el punto culminante del mito del rey Fernando VII, y por lo mismo el inicio de su disolución ${ }^{43}$. Su toma de partido a favor del absolutismo regio, con la consiguiente abolición del texto constitucional aprobado en 1812, será la causa para la ruptura del consenso que en torno a su figura se había gestado en sus años de cautiverio, y cuya fragilidad quedó manifiestamente al descubierto en 1814, dando paso a los convulsos enfrentamientos de su reinado entre absolutistas y liberales. A manera de ejemplo reseñaremos algunos de los actos celebrados en Galicia y algunos de los conceptos que en ellos se vertieron sobre la persona y significación de Fernando VII.

El monarca entró en territorio español el 24 de marzo. Su vuelta fue acogida con grandes muestras de júbilo, no sólo en aquellos lugares por los que pasó hasta llegar a Madrid, sino en todas las ciudades de la Co-

En una de las muchas coplas que circularon en aquellos días se decia: “Por esto diz o meu cura./ todos apreten os puños/ pola Patria e polo Rei./ E morrer por Dios, con gusto" (letrilla citada en Barfe Iro Fernandez. X. R., Galicia. Historia. VII..., op. cit., pág. 101).

43 Para comprender la exaltación de Fernando VIl en 1814, debe tenerse en cuenta "la hipertrofia del mito monárquico en el transcurso de la guerra de la Independencia. A la increíble mitificación de la figura del «Deseado" por parte de la Iglesia sobre todo, hay que agregar la experiencia concreta de la población. pensada de acuerdo con aquellos moldes ideológicos tradicionales: los años de vacio monárquico, que nunca colmó la presencia en el trono de un usurpador extranjero, quedarán también asociados a los sufrimientos indecibles de la guerra y la ocupación. agravados en 1812 por una crisis de subsistencia excepcional. Un mundo sin rey. igual que un mundo sin religión. era un mundo desquiciado, presa del caos y la arbitrariedad de que los débiles y los pobres eran victimas principales" (TOFAAS ELIAS, J., Liberalismo y rebeldia campesina, 1820-1823. Barcelona, 1976. págs. 17-18). 
rona ${ }^{44}$. En Santiago se celebró la noticia en cuanto se conoció, el 4 de abril de 1814, con un inmediato lanzamiento de cohetes, repique de campanas y un solemne Te Deum; en el acta consistorial se informa que:

"la tropa puesta sobre las armas recorrió las calles, el señor Gobernador Militar, xefes y oficiales la mayor parte montada en caballos enjaezados, con el retrato de Su Majestad» 45

Esto sucedió por la mañana; por la tarde, a partir de las ocho, hubo otro lanzamiento de cohetes, actuación de la música de la Escuela Militar en los balcones del ayuntamiento, repique general de campanas hasta la medianoche y luminarias en la catedral, monasterio de San Martín Pinario, Hospital Nacional, palacio arzobispal y otros edificios de la ciudad. Se abrió además una suscripción para recoger donativos destinados a los encarcelados, a la tropa y a los prisioneros franceses. En todo, se dice, fue "general el contento y alegría de este pueblo" ${ }^{46}$. En Betanzos la noticia se celebró los días 10,11 y 12 de abril, y al igual que en Santiago se dispusieron diversos actos religiosos y cívicos ${ }^{47}$.

En estas y otras ciudades se puede apreciar el esfuerzo realizado por el conjunto de la nobleza y el clero por monopolizar y rentabilizar en su favor la imagen del rey. Se trataba de exponer públicamente que el regreso del monarca era además la vuelta al sistema anterior; una expresión que romperá todos los diques para mostrarse con toda su crudeza cuando al poco tiempo Fernando VII, escudándose en el memorial conocido por el Manifiesto de los persas, firme el 4 de mayo un decreto anulando todas las reformas gaditanas, incluyendo claro está la Constitución.

\section{EL ABSOLUTISMO EN LAS CALLES}

Esta decisión real supone, como ya hemos dicho en varias ocasiones, el inicio de un cambio drástico en los contenidos de las celebraciones públicas, y que no es más que una manifestación externa de los movimientos políticos y sociales que se habian ido gestando desde las décadas finales del siglo XVIII, y que sucintamente reseñamos en el apartado dedicado a la

H. Un breve resumen de este viaje de regreso del monarca y de los cambios que introdujo en el programa previsto, en SANChez MANTero, R.. Fernando VII. Un reinado polémico. Madrid. 1996. págs. 58-62.

AHUS, Fondo Municipal de Santiago, Libro de Consistorios de 1814, enero-abril, f. 331 vto. lbidem, fs. 331 vto. -332

Se reseñan en Martinez Sanilso, M., Historia de la... op. cit., pág. 425 
situación general de Galicia. Por eso, aunque nos refiramos tanto en este apartado como en el siguiente a las ceremonias públicas posteriores a 1814, haremos referencias a manifestaciones públicas de los principios absolutistas o liberales, según sea el caso, de los años en los que Fernando VII estuvo cautivo. Si no las incluimos al hablar de este período ha sido por claridad expositiva, pues entendemos que lo fundamental de aquellos años fue la exaltación del rey junto con los principios tradicionales o reformadores.

La elaboración ideológica del absolutismo tanto en España como de manera particular en Galicia ha sido estudiada con acierto y extensión por Javier Herrero y Xosé Ramón Barreiro ${ }^{48}$. De sus obras retendremos algunos rasgos relativos a la configuración de los mitos elaborados por el absolutismo. Así conviene fijar la atención en la creación de los mitos antiilustrados y antiliberales por parte de los sectores reaccionarios, mitos que según Herrero se mueven alrededor de una supuesta triple conspiración: la de los filósofos con su exaltación de la razón, la de los jansenistas con su propuesta de libertad religiosa, y la de los masones con su intención de llevar a la práctica los ideales de razón, derechos humanos y libertad ${ }^{49}$. $Y$ conviene retener que desde el punto de vista político y social, el pensamiento reaccionario se apoya en la cerrada defensa del origen divino de la autoridad, que recae de tal forma sobre el soberano que éste adquiere un carácter sagrado, su poder resulta ser absoluto y al que los ciudadanos deben prestar sumisión ciega, habida cuenta no sólo de la sacralidad y poder reales sino también de la natural jerarquización de la sociedad ${ }^{50}$. De todo esto encontramos manifestaciones más que elocuentes en las ceremonias públicas; de esta forma, los contenidos de los tratados de los grandes maestros de la llamada tradición española (que según demostró Herrero, no era ni tradición ni española) se trasladan a las calles y a otros escenarios de las ceremonias, transformados en imágenes y palabras que llegan a un público más amplio.

El periodo en el que tal vez con más virulencia se muestra la eficacia de los mitos absolutistas en su reacción frente a los principios ilustrados y liberales, corresponde a los meses inmediatos al 4 de mayo de 1814, fecha de la abolición de la Constitución de 1812. Se abandona la imagen de Fernando VII como mártir cautivo de la patria en favor de su ima-

HF RHERO, J., Los origenes del pensamiento reaccionario español. Madrid, 1973; y X. R. BARRE HO FEFNANDEZ, Liberales y absolutistas..., op. cit.

HerRERO, J., op. cit., págs. 22-24.

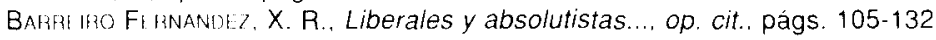


gen como monarca absoluto y cúmulo de todas las virtudes, que hará progresar a sus vasallos ${ }^{51}$; afirmación que será tanto más pasional y violenta cuanto que resultaba imposible por medio de una persuasión racional habida cuenta del agotamiento al que ya había llegado la sociedad del Antiguo Régimen. Pasión y violencia que se manifiestan en las celebraciones de la restauración absolutista, y a las cuales señala Herrero como suficientes:

"para introducirnos en el estado de delirio al que las emociones políticas y la continua acción del mito (...) habian llevado a un pueblo que renunciaba a la razón para buscar su salvación en el mesianismo absolutista» 52 .

En Santiago, según se cuenta en un acta municipal del 17 de mayo, el pueblo se reunió bajo los balcones del ayuntamiento con «aclamaciones por la exaltación y restitución al trono de nuestro amado soberano y de que muera la Constitución" ${ }^{53}$. Se quemó un ejemplar de la misma y se arrancó el rótulo que nombraba a la plaza como Plaza de la Constitución. La pasión dio entrada a la violencia, y así se nos informa en el mismo texto que ca pretexto de liberales extremados en el desafecto a la soberania del Rey, adictos a la Constitución", fueron perseguidos y arrestados varios ciudadanos compostelanos ${ }^{54}$. En Lugo se asiste a comportamientos similares; las gentes se agolparon delante de las casas consistoriales para pedir que se quemase el ejemplar de la Constitución que se conservaba en el ayuntamiento, y que se quebrase la piedra con la inscripción "Plaza de la Constitución. Año Segundo" ${ }^{55}$. En otra de las capitales del Antiguo Reino de Galicia, Betanzos, se celebró la abolición constitucional del 17 al 19 de mayo con los actos que podemos considerar habituales: concentración de gente con gritos a favor de Fernando y en contra de la Constitución, rotura de la lápida que daba nombre a la plaza

Sobre este cambio de imagen en Fernando VII, VEGA, J., El origen de la litografía en España. El Real Establecimiento Litográfico. Madrid, 1990, pág. 203. En palabras de HERHF-HO. J., "Probablemente, y con la excepción de los emperadores romanos y de los lideres totalitarios modernos, ningún rey. Luis XIV incluido, ha recibido una adulación tan extravagante y tan burda como la de Fernando VII a raíz de la guerra de la Independencia" (HERRE.RO. J., Los origenes del pensamiento reaccionario.... op. cit., pág. 389)

HEHAERO, J., Los origenes del pensamiento reaccionario..., op. cit., pág. 398.

AHUS, Fondo Municipal de Santiago, Libro de Consistorios de 1814, mayo-octubre, is 448 y vto.

Ibidem. El texto senala el afán de protección de las autoridades, que les lleva a encarcelar a estos disidentes para evitar "el furor del populacho"; en realidad, es muy posible que el incidente fuera aprovechado -o provocado- para represaliar a liberales destacados.

is Rodniguez Ronhigut?, L. Los liberales lucenses (1808-1854). Sada (La Coruña). 1981. pág. 103. Estos actos se celebraron el 16 de mayo. 
mayor, misa de acción de gracias con Te Deum, procesión con el retrato del rey en un carro triunfal, luminarias y otros ${ }^{56}$. En otras ciudades se asistió no sólo a la quema del texto sino a su arrastre por las calles por medio de burros, o a su lanzamiento desde un puente a las aguas de un río ${ }^{57}$. Las celebraciones por la derogación de la Constitución y las demás reformas gaditanas se continuaron con otras próximas, como la onomástica real el 30 de mayo y la reposición de la Inquisición en julio del mismo año ${ }^{58}$. En general -y en particular - destacaron esas dos notas anteriormente citadas, la pasión y la violencia, a favor de una postura política que adolecía de apoyo racional suficiente.

Con menos violencia pero no con menos pasión los partidarios de la tradición defendieron sus posiciones en aquellos años -que fueron muchos- del reinado de Fernando VII en los que tuvieron en sus manos las riendas de la cosa pública. Se aprovecharon para ello de todas las ocasiones posibles para ensalzar la monarquia absoluta y todo lo que ello suponia. Las arquitecturas efimeras y los cortejos callejeros de las corporaciones urbanas fueron medios de difusión adecuados para tratar de apuntalar un edificio cada vez más agrietado, aunque como señalamos anteriormente en Galicia se resistía tenazmente a caer. Para no alargar en exceso la exposición nos referiremos únicamente a los componentes más explícitos de las ceremonias públicas, como son los textos impresos en los que se recogieron los sermones y otras intervenciones; en ellos se exponen algunos de los principios del pensamiento reaccionario anteriormente citados.

Así, nos encontramos ataques furibundos contra los filósofos, a los que se acusa de crueldad y de ser contrarios a todo respeto a los hombres y su naturaleza ${ }^{59}$; y por supuesto contra la masonería y otras sociedades,

Martinez Santiso, M., Historia de la ciudad..., op. cit., págs. 425-428.

En Barreitio Fernandez. X. R., Galicia. Historia. VII... op. cit, págs. 192-193, se encontrarán diversas celebraciones que tuvieron como escenario a Tuy, Orense y Armenteira.

Sobre la celebración del restablecimiento de la Inquisición en Santiago, Lopez, R. J., Ceremonia y poder en Galicia a finales del Antiguo Régimen. Santiago de Compostela, 1995, págs. 140-141. En cuanto a la onomástica real, hay que señalar como hecho curioso el lanzamiento de un globo en Betanzos la noche del 29 de mayo. uso empleado luego en otras fiestas políticas y religiosas y que se ha convertido actualmente en el centro de atención de las fiestas locales; véase Erias Martinez, A., "El globo de Betanzos, protagonista de las fiestas políticas y religiosas del s. XIX y más allá, en ERIAS, A. (coord.). El globo de Betanzos. Madrid. 1996. págs. 3-89.

"Cesad de atronarnos, filósofos entusiastas, con el grito de esa decantada humanidad. que pretendéis sustituir a la caridad evangélica. ¿Qué ventajas ha producido al género humano la algazara misántropa de los filántropos? ¿Se ha visto nunca más ultrajada la humanidad, ni menos respetadas las virtudes humanas, que desde la época en que las bocas impias empezaron a vociferar humanidad en odio a la Religión? Gentes estólidas, ya veis establecido en la Europa el fatal imperio de la inhumanidad y barbarie, bajo el salvo conducto de aquellas máximas impostoras" 
cuya maldad las lleva no sólo a luchar contra el orden tradicional sino entre ellas ${ }^{60}$. Cualquier ocasión era propicia para subrayar la tesis del origen divino del poder, sobre todo si se trataba de una ceremonia relacionada con la familia real ${ }^{61}$. Un origen que debe llevar a respetar a los reyes como padres de sus súbditos y a obedecerlos sin crítica alguna ${ }^{62}$; porque cuando no se respeta lleva a los mayores desastres, como justo castigo al olvido de la sumisión debida a Dios y a los reyes que lo representan en la tierra ${ }^{\text {} 3}$.

\section{EL LIBERALISMO Y SUS MITOS}

Para la defensa y difusión de sus principios y propuestas de transformación, los liberales recurrieron también a la mitificación, a la construcción de una serie de símbolos e imágenes que sirviesen para su enraizamiento en la opinión pública. Como en el caso de los absolutistas, esa mitificación afectará tanto a personas como a alguna de sus realizaciones y conceptos generales. Esta mitología liberal saldrá a la calle con ocasión de la

(Rooriguez Gayoso, M.. Oración fúnebre histórico-moral que el monasterio de San Salvador de Celanova [Orense] consagra a la buena memoria de su hijo benemérito el llustrisimo Señor D. Fr. Benito Uría y Valdés, obispo que fue de Ciudad-Rodrigo. Imp. de Juan Francisco Montero. Santiago, 1811, págs. 40-41).

"Los Masones se jactan de pertenecer a una sociedad tan ilustrada y tan iluminada. Los Comuneros se manifiestan sus rivales. Los del Anillo. los Materialistas, los incrédulos y repetidas facciones de calvinistas, sectarios de Rousseau, Voltaire y más heresiarcas, son los que brillan en el mundo español, son los que hormiguean por esas calles y plazas vomitando todo género de inmundicias, injurias e insultos contra la religión de Jesucristo" "Manifiesto de las funciones reales celebradas en la ciudad de Vigo en los dias 15, 16 y 17 de noviembre de 1823. Imp. de Pascual Arza. Vigo. 1823, págs. 3-4).

En las exequias celebradas en Orense a la muerte de María Luisa de Borbón. se insiste en la necesidad de rezar primero por los reyes antes que por cualquier otra persona, porque "sus almas conservan un derecho de preferencia en el orden de la caridad como imágenes del mismo Dios y especiales ministros suyos por el poder y autoridad que recibida de su mano ejercieron en su nombre" (BEDOYA, J. M. Sermón en las solemnes exequias... por la señora... Doña María Luisa de Borbón. madre del Rey Nuestro Señor Fernando VII. Imp. de Juan María Pazos. Orense. 1819. pág. VI); el sermón continúa con un elogio de los bienes que los súbditos reciben de sus soberanos. y por supuesto con la exaltación de las buenas prendas de la mujer de Carlos IV.

"No por otra razón el rey es mirado como padre de sus pueblos, sino porque éstos le deben como hijos obediencia. Mas nunca toca al hijo más que obedecer, sin que pregunte porqué se le manda" (VARELL. J., Sermón que en la... acción de gracias... por el feliz enlace de nuestro Soberano con... Doña Maria Cristina de Borbón, dedicó el Ayuntamiento de... Lugo.... Oticina de José Fermin Campaña. Santiago. 1830. pág. 31).

"Los padecimientos y males de época tan desastrosa [1820-1823] fueron obra de Dios, justamente irritado por nuestros pecados, y el librarnos de ellos efecto saludable de su gran misericordia" (BAzAN. J. M., Sermón... en la solemne función de acción de gracias que hizo el cabildo catedral.. de Tuy por la libertad de S.S.M.M. Imp. de Miguel de Burgos. Madrid, 1824, pág. 4). 
proclamación y jura de la Constitución de 1812 y de las ceremonias públicas del Trienio Liberal, y de esta manera se dará a conocer una serie de planteamientos políticos, sociales y económicos que responden de forma genérica a los intereses de la burguesía. Se trata de popularizar principios tales como el de la libertad e igualdad, la soberanía nacional, el parlamentarismo, el derecho a la propiedad, entre otros. La monarquía cede parte de su protagonismo en favor de la Constitución, y el pueblo sustituye al rey como depositario de la soberanía; las diferencias, por tanto, con el planteamiento teórico de los absolutistas y, por consiguiente con su propaganda son radicales. Nos fijaremos principalmente en dos tipos de acontecimientos de la propaganda liberal a través de las ceremonias públicas: la proclamación constitucional de 1812 y la conversión en mitos de algunos protagonistas del liberalismo gallego.

La jura de la Constitución de 1812 fue la ocasión para que por vez primera de forma solemne, los principios reformistas se expusieran públicamente. En las villas y ciudades se levantaron arquitecturas efímeras alusivas a los bienes que proporcionaría el nuevo régimen y a los ideales que lo sustentaban, y para que no quedase duda alguna en el ánimo de los asistentes a los actos y espectáculos festivos, se acompañaron de textos que hacian explícitos el contenido de todos los símbolos y en particular de los que podían resultar más oscuros. Así, el acto de jura de la Constitución fue precedido, acompañado y continuado por artefactos y actividades con un gran contenido propagandístico, que trataban de lograr la mayor adhesión posible al texto y a las reformas políticas y de todo tipo que éste implicaba ${ }^{64}$. En nuestro caso, el de Galicia, nos encontramos con informaciones más que suficientes para ilustrar tal carácter pedagógico y propagandístico.

En Noya, una pequeña villa marinera de la actual provincia de La Coruña, la proclamación y jura se celebró los días 20 y 21 de septiembre. De entre las construcciones efímeras, queremos destacar la representación central del templo de Themis que se levantó para la ocasión: un retrato de Fernando VII en el que aparecía una alegoría de España, que al tiempo

Véase LORENTE, M., "El juramento constitucional". Anuario de Historia del Derecho Espa ñol. LXV (1995), págs. 585-632. La autora destaca entre otros aspectos el carácter pedagógico de la jura de la Constitución de 1812: "la publicación y juramento de la Constitución fue, además de todo lo afirmado aqui, un auténtico ejercicio de educación popular. Una educación que al mismo tiempo que pretendia dignificar a los individuos a través del reconocimiento de derechos previos, también imponia una estructura y una organización estatal ajena a muchas tradiciones jurídicas. estructura y organización que se intentó hacer interiorizar como si de una nueva religión laica se tratase " (pág. 632). 
que coronaba al monarca le entregaba un ejemplar de la Constitución. De esta forma tan gráfica, se expresaban dos conceptos: la nación como depositaria de la soberanía (por tanto, la que coronaba al rey), y la nación que en virtud de su soberanía y libertad elegía el modo en que quería organizarse y gobernarse (decisión que se expresa en la entrega imperativa al monarca del texto constitucional) ${ }^{65}$. Como en cualquier otra ceremonia pública precedente, también en este caso los gremios se aprestaron a participar cada uno con su comparsa representando diversos motivos y portando letrillas alusivas al caso. Llama la atención la representación conjunta entre las comparsas del gremio de los carpinteros y el de los sastres, que mediante danzas y con los versos que portaban escenificaron la liberación que para los españoles significaba la Constitución; se hacía hincapié de este modo en conceptos tales como libertad e imperio de la ley frente al gobierno arbitrario y despótico ${ }^{66}$

En la ceremonia de proclamación que tuvo lugar en Santiago desfilaron varios figurantes que representaban diversos conceptos relacionados con el ideario liberal burgués: el Patriotismo, la llustración, la Prosperidad, la Aplicación, la Agricultura y el Gobierno, entre otros ${ }^{67}$. Cerraba este cortejo simbólico que recorrió las calles compostelanas el 5 de julio, una pareja sobre un carro triunfal: la Nación y el Rey ${ }^{68}$. Al igual que en Noya, la disposición y actitudes de los figurantes representaban el nuevo orden sobre el que se apoyaba la Constitución, haciendo especial insistencia en la soberanía de la nación y el pacto entre ésta y el soberano representado por la entrega de la Constitución; la descripción de la pareja es la que sigue:

"La Nación colocada en un solio precioso, magnificamente vestida, llevaba en la cabeza una corona de plata, como insignia principal y propia que le corresponde como Soberano, y en quien reside el poder legislativo; llevaba

\footnotetext{
La descripción del templo en Relación de las funciones que hizo... la villa de Noya... con motivo de la publicación de la Constitución politica de la Monarquia Española, Oficina de Antonio Rodríguez. La Coruña, 1812, págs. II-VI. Nos ocupamos de este templo y otras construcciones en Ceremonia y poder en Galicia..., op. cit., págs. 92-95.

Relación de las funciones..., op. cit., pág. $X$

Los actos se celebraron los días 4 y 5 de julio. se recoge la crónica de un diario de la época, la Gaceta Marcial y Politica, en Perez Costanti, P., Notas viejas galicianas, 1. III. Vigo, 1927, págs. 217-224. El proyecto de los actos y su discusión en AHUS, Fondo Municipal de Santiago, Libro de Consistorios de 1812, enero-julio, fs. 360-362 y 363-365vto

;: El carro fue construido por el escultor Manuel de Prado; unos meses después el escultor presenta su cuenta de gastos, ante la que el ayuntamiento acuerda "no haber lugar a lo que pide dicho Prado" (AHUS, fondo Municipal de Santiago, Libro de Consistorios de 1812, agosto-diciembre, f. 70vto.).
} 
en la mano el libro de la Constitución que le entregaba al Rey, colocado a su izquierda y el que llevaba el cetro como signo del poder ejecutivo" ${ }^{69}$.

En fin, todo - las comparsas, los bailes, las decoraciones de las fachadas, el templo levantado a la Constitución, el propio acto de la juracontribuyó en palabras del escribano municipal:

"a la celebridad de la publicación y jura de la Constitución, cuyo digno objeto es la libertad de la Nación Española, conservación de su Religión (...) y la consolidación de sus leyes fundamentales para el mejor bien estar, alivio y felicidad de los pueblos de la Monarquía” ${ }^{70}$.

De lo sucedido en otras ciudades como Betanzos, Ribadeo y Lugo tenemos también noticias ${ }^{71}$. Es interesante destacar las discrepancias que surgieron en esta última, y que provocaron un considerable retraso en la jura de la Constitución. Los actos estaban previstos por el ayuntamiento lucense para los dias 6 y 7 de agosto; la proclamación se celebró el dia 6 , pero al siguiente no se pudo proceder a la jura por la ausencia del clero por la oposición del obispo a que se utilizase la catedral para el acto de jura constitucional. Por fin se llegó a un arreglo para que la función se celebrase en una de las capillas más amplias del templo el 20 de septiembre ${ }^{72}$.

La pericia de los liberales para el empleo de los instrumentos de mentalización colectiva se puso de manifiesto en la mitificación no sólo de la Constitución, sino sobre todo en la exaltación de sus héroes. En este proceso se dieron la mano dos ideas que si bien en un principio pueden parecer opuestas, en realidad no lo son: el héroe como representación de las virtudes populares, y el héroe como personaje sobrehumano y de calidad irrepetible ${ }^{73}$. El héroe liberal es el héroe que derrama su sangre y muere en defensa del pueblo; es por tanto un mártir de la libertad, cuya ejemplaridad de conducta deberá incitar a la imitación y con ella a la cohesión en torno al ideario burgués ${ }^{74}$. Para fijar en la opinión pública la imagen y sig-

Perez Costanti, P., Notas viejas..., op. cit., pág. 222.

AHUS, Fondo Municipal de Santiago, Libro de Consistorios de 1812, enero-julio, fs. 403vto404.

Martinez Santiso. M., Historia de la ciudad. op. cit., págs 414-420: F. Lanza Álvarez, Ribadeo antiguo. La Coruña, 1973, págs. 263-272

Rodriguez Rodricue ., L., Los liberales lucenses..., op. cit., págs. 99-100

58.

Seguimos aquí a BarRe iro Fernandez. X. R., Liberales y absolutistas..., op. cit., págs. 53 -

Que el héroe muerto es más “rentable» que el héroe vivo, lo demuestra la mayor eficacia de los mitos liberales sobre otros ya mencionado anteriormente, como el intento de glorificación del Marqués de la Romana y por supuesto del propio Fernando VII. 
nificación de estos héroes en la vida de la nación, se emplearon cauces diversos como la publicación de biografías y obras literarias de alcance popular, la dedicación de calles y plazas, la inscripción de sus nombres en un lugar tan significativo como el Salón de las Cortes, y por supuesto mediante la apoteosis pública de las exequias patrióticas ${ }^{75}$

Las exequias patrióticas de los mártires y beneméritos de la patria tenían un antecedente inmediato en las dedicadas a las víctimas del 2 de mayo a las que ya nos referimos anteriormente; y en general contaban con toda la tradición secular de las exequias reales. En tal sentido puede afirmarse que formalmente se ajustan a la tipología de éstas en el conjunto del ritual funerario, el levantamiento de alguna arquitectura efímera y la edición de la relación de los actos y del elogio del fallecido. Hay, sin embargo, algunas diferencias también formales entre las tradicionales exequias del Antiguo Régimen y estos funerales patrióticos: la procesión con los restos mortales del héroe, la celebración del funeral —al menos parte del mismo- en ocasiones al aire libre y no en lugar sagrado, aspectos que junto a otros contribuyen a que estas ceremonias de clara finalidad mitificadora tengan un perfil más marcadamente civil que religioso ${ }^{76}$. Resulta evidente en cuanto al fondo de estas ceremonias que su modelo no fueron las exequias reales, sino las celebraciones cívicas inauguradas por la Revolución Francesa y a las que también nos hemos referido en páginas precedentes.

Los tres primeros héroes liberales gallegos fueron Sinforiano López, ejecutado en La Coruña en 1815; Juan Díaz Porlier, ejecutado en octubre de 1815 tras el fracaso de su pronunciamiento militar; y Félix Álvarez Acevedo, comandante general del ejército revolucionario de Galicia, muerto en acción militar en marzo de 1820. De los tres, conocemos el elogio fúnebre de Acevedo y sobre todo las exequias de Porlier, el elegido por su trayectoria militar y en la defensa del liberalismo para encabezar su panteón del hombres ilustres ${ }^{77}$. Su mitificación comienza el día 8 de abril de

Diversa documentación sobre la inscripción de los nombres de Félix Álvarez Acevedo y Juan Díaz Porlier en el Salón de las Cortes y sus nombramientos como ubeneméritos de la Patria", en Meijlde Pardo, M. L., Contribución al estudio del liberalismo. Sada (La Coruña), 1983 págs. 285-295.

Seguimos las conclusiones de FERRER MARTi, S. "Los funerales patrióticos valencianos: similitudes y diferencias con las exequias reales del siglo XIX». Millars, 15 (1992), págs. 124-132.

VERDES, J., Oración fúnebre que en el entierro del benemérito mártir de la Patria $D$. Félix Alvarez Acevedo, Comandante General de las Armas de Galicia dijo de orden de la Junta Suprema de Gobierno.... Imp. de Arza. La Coruña, 1820. Sobre Porlier, véase la reciente biografía de De BARTHE. I.MY, R. G., "El Marquesito" Juan Diez Porlier. "General que fue de los Ejércitos Nacionales... (1788-1815), 2 vols. Santiago de Compostela, 1995; sobre sus exequias de 1820, BAfrreiro Fernandez, X. R., "A glorificación de Porlier", introducción de Crespo CaAmano, C., Porlier. Crónica documentada do levantamento de 1815. La Coruña, 1989, págs. 11-22. 
1820, con la exhumación de sus restos del lugar en el que fueron enterrados tras su ejecución, y su posterior traslado a la capilla coruñesa de San Roque. Aquí permanecieron mientras se labraba un sepulcro a la altura de las circunstancias, hasta su nueva inhumación el 5 de mayo. Entre tanto, se celebraron varios actos que contribuyeron al ensalzamiento de Porlier y con él del liberalismo: una representación teatral (Porlier en la última hora, de José Urcullu), la solicitud para dar su nombre y los de Acevedo y Lacy a tres calles importantes de La Coruña, y el acto solemne de su rotulación. El día 4 de mayo se lleva en procesión por las calles herculinas el sarcófago con los restos de Porlier, con rendimiento de máximos honores militares a su paso y disparo de salvas cada media hora. Al llegar a la Plaza de la Leña, donde había sido ejecutado en 1815, se quemó la horca y se soltaron palomas blancas que portaban cintas con la palabra libertad. Desde alli se fue a la iglesia de San Jorge, en la que se celebró la función religiosa con el correspondiente elogio de Porlier. Al día siguiente, el 5 de mayo, fue el entierro en la capilla de San Roque; al tiempo de enterrarlo, el clérigo que el día anterior predicara en el funeral pronunció las siguientes palabras que expresan el grado de idealización y de ejemplaridad al que estaba siendo llevada la figura de Porlier:

“Adiós caras cenizas, adiós ilustres restos (...). Si la tiranía sacrificó tu vida alevosamente, el patriotismo de una ciudad heroica te ofrece estos obsequios y estos sufragios (...). Todos se inflaman al contemplar tus venerables huesos y pueden tanto en las almas libres, que si alguno intentase encender otra vez la tea de la discordia, te sacariamos por esas calles en hombros de patriotas, para que el ver tu sepulcro quedasen aterrados los malvados» ${ }^{78}$.

Al finalizar el acto, algunas mujeres pidieron llevarse los ramos de ciprés empleados en la función; la mitificación de Porlier ya estaba en marcha ${ }^{79}$.

\section{CONCLUSIÓN}

En un trabajo como el presente, resulta difícil que una vez llegados al capítulo de conclusiones, éste pueda realmente ser lo que de él se espe-

\footnotetext{
: Texto de PACheco Vermudez, A., Breve descripción de las solemnes honras fúnebres que se hicieron en La Coruña al general D. Juan Diaz Porlier, 1820, citado en Barreiro Fernández, X. R., "A glorificación...", op. cit., pág. 15.

El proceso de conversión de Porlier de héroe gallego en héroe del liberalismo español, y la difusión de su imagen por Europa, en Babreiro Fernandez, X. R., "A glorificación...", op. cit., págs. 16-17.
} 
ra, un resumen de resultados claros y distintos, por usar el tópico cartesiano. El estudio de las ceremonias públicas resulta ser un campo apasionante por la cantidad de sugerencias que provoca; al fin y al cabo, estos actos públicos son un reflejo de la sociedad que los genera, de manera que para comprender en profundidad sus significados y funciones no parece que haya otro medio que el de ir profundizando en aquellas cuestiones que suscita. Una profundización en la que se corre el riesgo de la dispersión con la consiguiente confusión analítica, riesgo que al tratar de evitarse puede llevar en otra dirección también peligrosa, la de polarizar en exceso el estudio mediante la insistencia en una determinada línea interpretativa en detrimento de otras posibles. De ahi que afirmemos la dificultad de poder presentar resultados claros y distintos; es decir, resultados que satisfagan las múltiples expectativas que origina el tema en cuestión.

En nuestro caso hemos intentado situar unas líneas básicas por las que pudiera discurrir el análisis de las ceremonias públicas de un período tan convulso para la historia de España como lo fue el reinado de Fernando VII, tomando como referencia las ceremonias celebradas en Galicia. Para ello optamos por un criterio interpretativo de fondo, el de considerar las ceremonias del período como un vehículo más para la creación de la opinión pública, y aplicar a aquéllas los rasgos de ésta (Habermas). Por otra parte, nos parecía que otro segundo criterio básico era que una vez señalada la referencia general anterior, debía trazarse el contexto particular en el que se desarrollaron las ceremonias objeto de estudio; en este caso, la evolución de Galicia en la crisis del Antiguo Régimen, la cual ayuda a comprender mejor los intereses y fuerzas que se manifiestan y enfrentan a través del ceremonial y la celebración.

En su conjunto, el análisis a partir de estos criterios nos ha permitido entender las ceremonias públicas gallegas de los años 1808-1833 como la manifestación de una sociedad que se debate entre dos grandes modelos socioeconómicos, el de la tradición y el de la modernidad, y en el que el peso del primero es abrumador, de manera que las ceremonias dejan de tener el perfil relativamente homogéneo que presentaban en el Antiguo Régimen para ofrecer otro que refleja a las claras su inserción en una sociedad inmersa en una de crisis de cambio ${ }^{80}$. Esta situación de las ceremonias públicas entre la tradición y la modernidad que acabamos de señalar genéricamente, se puede concretar en ciertos aspectos que de un modo u otro hemos ido viendo en estas páginas; aspectos que lejos de ser

\footnotetext{
Sobre las ceremonias públicas del Antiguo Régimen en Galicia, véase BARRIOCANAL LOPEZ, Y., Exequias reales en la Galicia del Antiguo Régimen. Poder ritual y arte efímero. Vigo, 1997.
} 
independientes unos de otros, van profundamente entrelazados. En resumen, podemos describir las ceremonias del período como ceremonias entre la tradición y la modernidad por varias razones: a) porque continúan manteniendo formalmente la estructura y programa desarrollado durante el Antiguo Régimen, pero modificado por la contención y racionalismo de la estética neoclásica y por la sensibilidad romántica; b) porque si bien todas ellas responden a la función tradicional de la ceremonia de manifestar solemnemente el poder y sus fundamentos, en este período se le añade una función en cierto modo nueva tanto por parte de los absolutistas como de los liberales, la de servir de vehículo para convencer a la opinión pública de las bondades de sus propuestas de organización política y económica; c) porque en consonancia con esta función, encontramos en los contenidos de las ceremonias la proyección de los principios ideológicos y de los intereses socioeconómicos de los dos modelos en pugna; y d) porque según sea el caso, los promotores y protagonistas principales de las ceremonias serán los grupos dominantes del Antiguo Régimen (nobleza y clero) o la burguesía ascendente.

Las ceremonias del reinado de Fernando VII necesitan de un estudio más detenido, y del que éste no ha sido más que un intento. Las conclusiones que presentamos no son en realidad más que propuestas en las que se debe seguir profundizando y a las que sin duda habrá que añadir otras que en nuestro texto apenas si se mencionan al pasar, como por ejemplo el análisis de los efectos y de la eficacia de estas ceremonias. 